\title{
Calcium physiology of sweet cherry fruits
}

\author{
Andreas Winkler $^{1}\left[\right.$ D $\cdot$ Bennet Fiedler $^{1} \cdot$ Moritz Knoche $^{1}$ (D)
}

Received: 17 January 2020 / Accepted: 30 April 2020 / Published online: 16 May 2020

(c) The Author(s) 2020

\begin{abstract}
Key message Xylem functionality is the primary determinant of the Ca relations of developing sweet cherry. Calcium influx is positively related to transpiration and decreases as xylem functionality is progressively lost during development.

Abstract Fruit calcium (Ca) may be associated with susceptibility to rain cracking in sweet cherry but little background information is available on the fruits' Ca relations. The objectives of the study were to identify the key determinants of the Ca content in developing sweet cherry fruit. The masses of $\mathrm{Ca}$ and $\mathrm{K}$ in the flesh (mg per fruit) increased continuously through to maturity. However, their dry mass ratios [mg per g dry mass (DM)] decreased continuously. The decrease in Ca/ dry mass ratio was to about $30 \%$ of the transition stage II/III value, and for K to about $55 \%$. These decreases occurred in all cultivars investigated. Moreover, the $\mathrm{Ca}$ mass per fruit and the $\mathrm{Ca} / \mathrm{dry}$ mass ratio were normally distributed and wide ranging; the maximum recorded values were about twice the minimum ones. Within a fruit, the Ca/dry mass ratio was two to three times higher in the stem end than in the stylar scar end. Fruit held under low relative humidity (26.2\%) contained more $\mathrm{Ca}$ per fruit and had a higher $\mathrm{Ca}$ /dry mass ratio compared with fruit held under high humidity (91.6\%). There was a positive relationship between Ca mass per fruit and cumulative transpiration. Our results indicate xylem functionality is the primary determinant of the Ca relations of sweet cherry fruit.
\end{abstract}

Keywords Prunus avium $\cdot$ Cracking $\cdot$ Uptake $\cdot$ Penetration $\cdot$ Xylem

\section{Introduction}

Calcium plays an important role in the pre- and postharvest physiology of most fruit. Functions of $\mathrm{Ca}$ include signal transduction as a secondary messenger (Hardingham and Bading 1999; Steinhorst and Kudla 2014), the maintenance and regulation of membrane semi-permeability (van Steveninck 1965; Poovaiah and Leopold 1973; Hepler 2005) and the structural reinforcement and cross-linking of cellwall constituents (Demarty et al. 1984; Chan et al. 2017). The latter functions are associated with apoplastic $\mathrm{Ca}$. This Ca pool constitutes by far the largest in a fruit (Demarty et al. 1984).

Communicated by L. Kalcsits.

Moritz Knoche

moritz.knoche@obst.uni-hannover.de

1 Institute of Horticultural Production Systems, Leibniz-University Hannover, Herrenhäuser Straße 2, 30419 Hannover, Germany
Because fruit firmness is an important quality attribute in many fruit crop species, pre- and postharvest applications of $\mathrm{Ca}$ are commonly made to improve these properties, including in apple (Conway et al. 2002; Schlegel and Schönherr 2002), tomato (Garcia et al. 1995; Islam et al. 2016) and sweet cherry (Winkler and Knoche 2019).

In sweet cherry, $\mathrm{Ca}$ is reported to positively affect fruitquality attributes such as firmness and cracking susceptibility [for review see Winkler and Knoche (2019)]. However, the effects are not always consistent. Thus, cracking susceptibility is markedly reduced by Ca treatments in some studies (Bullock 1952; Glenn and Poovaiah 1989; Meheriuk et al. 1991; Michailidis et al. 2017), while in other studies no Ca effect was found (Callan 1986; Koffmann et al. 1996; Looney 1985). To properly exploit the potentially positive effects of $\mathrm{Ca}$ applications on fruit quality in commercial production systems requires a better understanding of the $\mathrm{Ca}$ relations of developing fruit. To our knowledge, there are no detailed reports on fruit $\mathrm{Ca}$ relations in sweet cherry. In particular, the import of $\mathrm{Ca}$ to the fruit and its subsequent distribution within the fruit have not been investigated on 
a temporospatial basis. Because Ca transport is restricted to the xylem (Marschner 1995) and because, in a sweet cherry fruit, xylem functionality decreases during development (Brüggenwirth et al. 2016; Grimm et al. 2017; Winkler et al. 2016), the import of Ca to the fruit is most likely to be slowed and changes in fruit $\mathrm{Ca}$ relations are predicted to occur. In particular, during the later stage of fruit development, Ca import is expected to decline. Coincidentally, this will occur at much the same time as cracking susceptibility is known to increase.

Also, studies on Ca relations indicate that $\mathrm{Ca}$ transport is driven by transpiration. Hence, manipulating transpiration affected Ca import as was shown in kiwi when subjected to differential transpiration (Montanaro et al. 2015) or in tomato following spray application of abscisic acid (ABA) (de Freitas et al. 2014).

In contrast to $\mathrm{Ca}, \mathrm{K}$ occurs at high concentrations in the phloem. Hence, plant organs preferentially supplied by phloem sap such as fruit are typically rich in K (Mengel and Kirkby 1982). Three variables are useful in describing the changing mineral composition of a developing fruit: (a) solute mass per volume, (b) solute mass per fruit and (c) solute/dry mass ratio.

a Solute mass per volume (e.g., $\mathrm{mg} / \mathrm{ml}$ )—describes the concentration of each soluble moiety in the fruit per volume of solvent (water). Solute mass per volume is particularly relevant to fruit chemistry because chemical reactions are mostly concentration dependent. However, with strong tissue and cellular compartmentation of solutes, solute concentration measurements commonly offer an averaged, whole-fruit or whole-tissue, value. These values can obscure quite wide concentration differences among the various compartments, so are not very useful.

b Solute mass per fruit (e.g., mg per fruit)—describes for each solute moiety the net of the influxes/effluxes through the fruit-stalk vasculature that have occurred up to that stage of fruit development. Thus, changes in solute mass per fruit (the first differential of mass per fruit with respect to time) can be taken as indicative of the rates and directions of the phloem and xylem sap flows (the only pathways through which most of these solutes can enter/leave the fruit). This is particularly useful because some solutes (e.g., sugars) are transported exclusively in the phloem, while others (e.g., $\mathrm{Ca}$ ) are transported exclusively in the xylem (Marschner 1995). Moreover, while (it is believed) the phloem sap flows always from tree to fruit, the xylem sap can flow in either direction. That is, the speed and direction of xylem sap flow depend on the magnitude and direction of the water potential gradient between tree and fruit. With wide diurnal oscillations in tree water potential being the norm, the xylem sap can flow from fruit to tree in daytime and from tree to fruit at night (Lang 1990).

c Solute/dry mass ratio (e.g., mg/g dry mass)—describes the mass of a particular solute moiety in relation to the total dry mass of a tissue. Changes with time in the solute/dry mass ratio are useful in similar ways to those of solute mass per fruit, providing current information regarding the solute influxes/effluxes in the xylem and phloem saps. However, while solute mass per fruit is subject to very wide statistical variability between apparently similar fruits, the normalization offered by the solute/dry mass ratio can greatly reduce this variability.

The objectives of this study were (1) to quantify the Ca and $\mathrm{K}$ contents of developing sweet cherry fruit, (2) to determine the natural variation in Ca content of sweet cherry within the canopy (fruit-to-fruit variability with position in the tree) and across a range of cultivars (fruit-to-fruit variability between cultivars), (3) to identify potential relationships between fruit transpiration and fruit $\mathrm{Ca}$ import and (4) to quantify the effects of abscisic acid (ABA) on the Ca contents of fruit and leaves. Ca content was quantified as the $\mathrm{Ca}$ mass per fruit (mg per fruit) and the $\mathrm{Ca}$ /dry mass ratio (mg per g DM).

\section{Materials and methods}

\section{Plant material}

Sweet cherry fruit from the cultivars Adriana, Hedelfinger, Sam, Schneiders Späte Knorpel, Staccato and Sweetheart were sampled from greenhouse-grown or field-grown trees grafted on 'Gisela 5' rootstocks (P. cerasus L. $\times$ P. canescens Bois) at the Horticultural Research Station of Leibniz University in Ruthe, Germany (lat. $52^{\circ} 14^{\prime} \mathrm{N}$, long. $9^{\circ} 49^{\prime}$ E). The only exception was the 'Regina' fruit used in the study on the developmental time course of changes in $\mathrm{Ca}, \mathrm{K}$ and $\mathrm{C}$ content. For this, fruit was sourced from a commercial sweet cherry orchard in Gleidingen, Germany (lat. $52^{\circ}$ $16^{\prime} \mathrm{N}$, long. $\left.9^{\circ} 50^{\prime} \mathrm{E}\right)$. The trees were trained to a slender spindle. The soil nutrient level was optimum for potassium (18-20 mg per $100 \mathrm{~g}$ soil). Soil $\mathrm{pH}$ was slightly acidic (pH 5.5) to neutral ( $\mathrm{pH} 6.0$ ) for the loamy sand at Gleidingen and the loess at Ruthe, respectively. All fruits were cultivated according to current European regulations for integrated fruit production. No foliar fertilizers containing either $\mathrm{Ca}$ or $\mathrm{K}$ were applied to any trees used in this study. 


\section{General experimental procedure}

\section{Determination of fresh and dry mass}

Fruit flesh and pit were separated mechanically and weighed individually. Pit and flesh samples were frozen at $-20{ }^{\circ} \mathrm{C}$, freeze-dried for 3 to 4 days and then dried in an oven for 14 days at $103{ }^{\circ} \mathrm{C}$ and re-weighed.

\section{Contents of $\mathrm{Ca}$, $\mathrm{K}$ and $\mathrm{C}$}

Unless specified otherwise, the Ca content was determined only for the flesh. Flesh and pit were separated mechanically. Preliminary experiments established that destruction of the cuticle was essential for efficient lyophilization. Hence, stage III fruits were incubated in liquid nitrogen and subsequently crushed and freeze-dried for 3 to 4 days. For flesh samples of stage III fruit, an aliquot of about $8 \mathrm{~g}$ was dried in an oven at $103{ }^{\circ} \mathrm{C}$ for at least three to 4 days before grinding. For samples of stage II fruit, oven drying was not required, samples were ground directly. Grinding was carried out in a MM 400 mill (Retsch, Haan, Germany; 50-ml grinding jar, frequency $30 \mathrm{~Hz}$, duration $10 \mathrm{~s}$ for flesh or $30 \mathrm{~s}$ for pits). A $1 \mathrm{~g}$ sample of the powder was taken and further dried to constant mass for at least 3 to 4 days at $103{ }^{\circ} \mathrm{C}$. A $100 \mathrm{mg}$ aliquot was taken and ashed in a muffle furnace (L24/11/B180; Nabertherm, Lilienthal, Germany) at $500{ }^{\circ} \mathrm{C}$ (heating phase: from 20 to $500{ }^{\circ} \mathrm{C} 2 \mathrm{~h}$, holding phase: $4 \mathrm{~h}$ at $500{ }^{\circ} \mathrm{C}$ ). Occasionally ashing was incomplete. These samples were taken up in $200 \mu \mathrm{l}$ of $1 \mathrm{~N} \mathrm{HCl}$ and re-ashed using the same settings. The ash was then taken up in $2 \mathrm{ml}$ of $1 \mathrm{~N} \mathrm{HCl}$ plus $8 \mathrm{ml}$ of deionized water and filtered (MN 640 M; Macherey-Nagel, Dueren, Germany). $\mathrm{LaCl}_{3}$ was added to the solutions at a final concentration of $1 \%$ to eliminate interference in the $\mathrm{Ca}$ analyses by any P in the samples (Fishman and Downs 1966). The filtrate was diluted with deionized water as required to obtain a $\mathrm{Ca}$ concentration in the measuring window ( 0 to $4 \mathrm{mg}$ $\left.1^{-1}\right)$. Samples were analyzed using atomic absorption spectroscopy (AAS) (AAnalayst 300; Perkin Elmer, Waltham, MA, USA) equipped with a Ca lumina hollow cathode lamp (wavelength $422.7 \mathrm{~nm}$, slit $0.7 \mathrm{~nm}$ ) using an air-acetylene flame. Following an additional dilution step, the $\mathrm{K}$ content of the solutions was quantified by atomic emission spectroscopy (1100B; Perkin Elmer).

The $\mathrm{C}$ mass of the flesh in developing 'Regina' fruit was analyzed following drying and grinding. An aliquot of $30.0-41.5 \mathrm{mg}$ of dried powder was weighed into stannic cartridges for subsequent determination of $\mathrm{C}$ content using an elemental analyzer (vario EL cube; Elementar Analysensysteme, Langenselbold, Germany).

Each sampling comprised three biological replicates of 10-20 fruits each and two to three technical replicates. The only exceptions were samples taken at 15 and 23 days after full bloom (DAFB) during the developmental time course, when 30-53 fruits were used.

\section{Experiments}

\section{Developmental time course}

The developmental time courses of change in the $\mathrm{Ca}$ and $\mathrm{K}$ mass of flesh and pit, dry mass ratios of $\mathrm{Ca}$ and $\mathrm{K}$ and in $\mathrm{C}$ mass of the flesh were determined in developing 'Regina' fruit between 15 DAFB and 86 DAFB. Here, the Ca contents of flesh and pit were determined.

\section{Effect of cultivar}

Putative differences in $\mathrm{Ca}$ mass per fruit and $\mathrm{Ca} / \mathrm{dry}$ mass ratio among cultivars were investigated in 'Adriana', 'Hedelfinger', 'Sam', 'Schneiders Späte Knorpel', 'Staccato' and 'Sweetheart'. The Ca was determined in immature fruit (transition stage II/III, straw yellow) and also in mature fruit.

\section{Fruit-to-fruit variability}

The fruit-to-fruit variability in Ca mass per fruit and $\mathrm{Ca} / \mathrm{dry}$ mass ratio was determined in mature 'Sweetheart'. Here 40 randomly sampled fruit were analyzed individually.

\section{Position in the canopy}

Fruits taken from different positions within the canopy were analyzed for their $\mathrm{Ca}$ mass and $\mathrm{Ca} /$ dry mass ratio in 'Adriana'. Row orientation was from southwest to northeast. Comparisons were made between (1) top center, (2) midcenter and (3) base-center, and on either side of the row, i.e., (4) mid-northwest, (5) mid-southeast, (6) base-northwest and (7) base-southeast. All mid positions were at a height of about $1.5 \mathrm{~m}$ above the ground and all base positions were at about $0.5 \mathrm{~m}$ above the ground. The northwest and southeast orientations faced the alleys on either side of the row. Three biological replicates of ten fruits each per position were sampled from three different trees.

\section{Axial gradient within the fruit}

Putative axial gradients in $\mathrm{Ca} /$ dry mass ratio from the fruits stylar ends to their stem ends were investigated in 'Sweetheart' and 'Merchant' sweet cherry fruit. Fruits were cut transversely (i.e., normal to the stem/stylar-scar axis) into four slices of equal thickness, and the pit was removed. The slices were frozen, freeze-dried and analyzed as described above. The number of replicates was ten. 


\section{Effect of transpiration}

Putative relationships between fruit transpiration and $\mathrm{Ca}$ mass per fruit or between fruit transpiration and $\mathrm{Ca} / \mathrm{dry}$ mass ratio were investigated by manipulating the transpiration of greenhouse-grown 'Sam' fruit beginning at 13 DAFB. Working with fruit still attached to the tree, transpiration was changed by enclosing individual fruit in transparent polypropylene pottles (volume $120 \mathrm{ml}$ ). To increase transpiration, relative humidity (RH) was lowered by placing $25 \mathrm{~g}$ of dry silica gel in each pottle. To minimize transpiration, $\mathrm{RH}$ was increased by fruit transpiration in empty pottles. The fruit was introduced to the pottle through a $12-\mathrm{mm}$-diameter hole cut in the screw lid. The gap between stem and lid was sealed with a foam plug. The plug arrangement significantly reduced water vapor gain/loss from the pottle through the hole in the lid. Each setup was attached to the tree using thin wire. Sensors (logger: MSR147WD, sensor: FH2.3/160; MSR Electronics, Seuzach, Switzerland) were used to monitor the temperatures and humidities inside four such pottles-two representing the low-RH treatment (silica gel) and the other two the high-RH treatment (no silica gel) (Fig. 1).

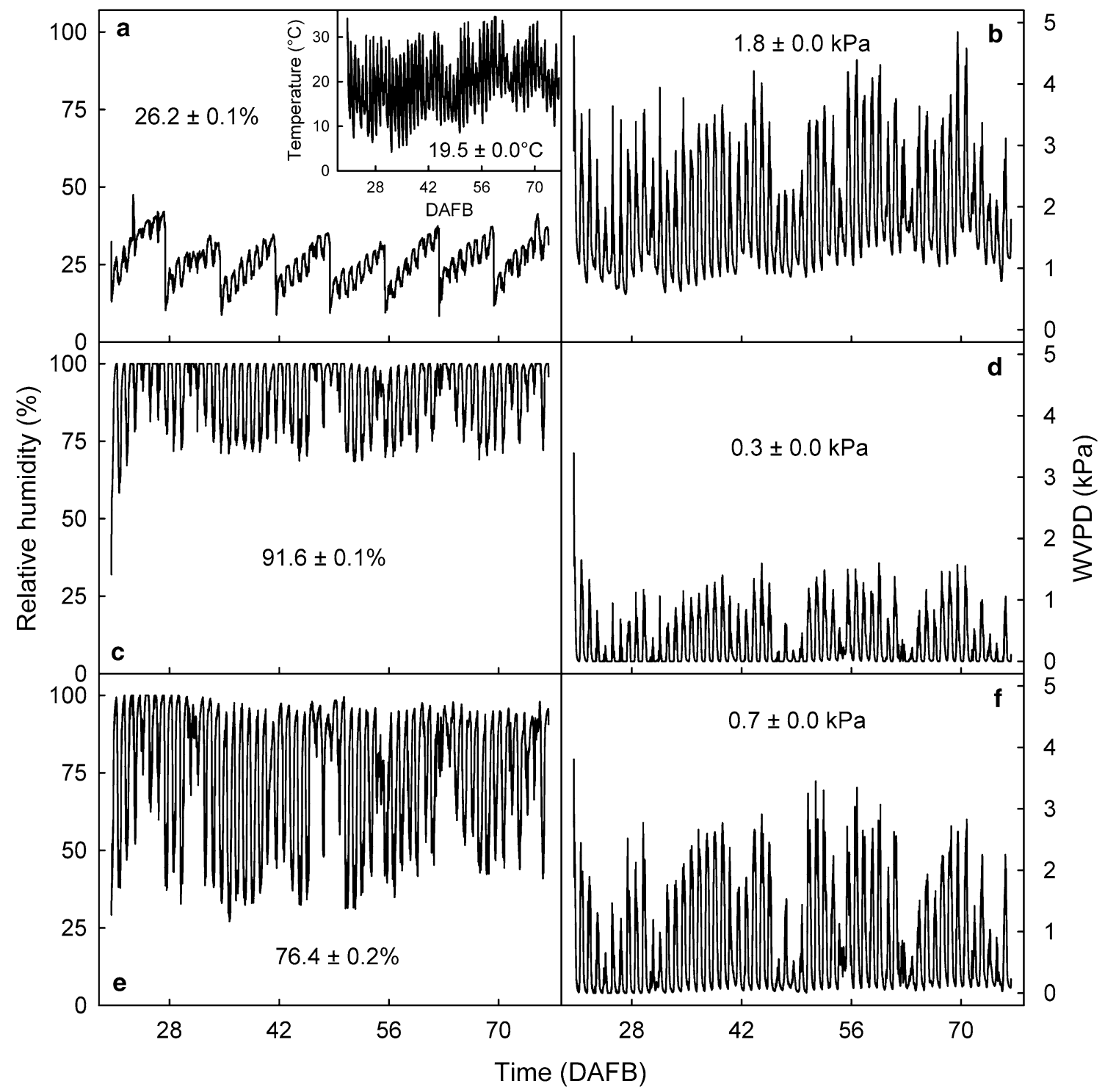

Fig. 1 Relative humidity (a, c, e) and water vapor pressure deficit (WVPD) (b, d, f) of fruit held at low $(\mathbf{a}, \mathbf{b})$ and high relative humidity $(\mathrm{RH})(\mathbf{c}, \mathbf{d})$ and control fruit $(\mathbf{e}, \mathbf{f})$. The low and high-RH environments were generated by sealing still-attached fruit within plastic pottles containing dry silica gel (low RH) or not (high RH). Fruits not within pottles (i.e., directly exposed to the greenhouse atmosphere) served as controls. The silica gel was replaced periodically. Repeated weighing of the silica gel allowed fruit transpiration to be quantified. There were no differences in temperature (c inset) between the treatments. Trees were grown in a greenhouse. Numbers in the graphs are means $\pm \mathrm{SE}$ 
In total, 150 fruits were mounted in pottles with silica gel and 150 fruits in empty pottles. In the pottles containing dry silica gel, a low RH (mean 26.2\%) and thus high water vapor pressure deficit (WVPD, mean $1.8 \mathrm{kPa}$ ) was established. In contrast, in the pottles with fruit but no silica gel, the RH was elevated (mean 91.6\%) and the WVPD was low (mean $0.3 \mathrm{kPa}$; Fig. 1). The pottles with dry silica gel were weighed and the silica gel was replaced weekly with freshly dried silica gel. Separate pottles without fruit but with dried silica gel served as controls to quantify diffusion of water vapor into the vessel. A third group of fruit remained hanging in situ in the tree (no pottle), being directly exposed to the greenhouse microclimate. For this group, the mean RH was $76.4 \%$ (corresponding to a WVPD of $0.7 \mathrm{kPa}$ ). Fruits were sampled at 27, 37, 48, 58 and 69 DAFB and fresh mass (FM), dry mass as well as Ca mass per fruit and $\mathrm{Ca} /$ dry mass ratios were quantified as described above. Three biological replications of ten fruits each were sampled for each treatment and date.

\section{Effect of abscisic acid}

The effects of abscisic acid (ABA) on Ca mass and $\mathrm{Ca} /$ dry mass ratios of 'Sam' sweet cherry were investigated. Whole trees were sprayed to run-off using a commercial formulation of ABA (ProTone SL; Valent BioSciences, Libertyville, IL, USA). The treatments were applied at weekly intervals starting from 14 DAFB to 81 DAFB (maturity) at a concentration of $400 \mathrm{mg}^{-1}$. The non-ionic surfactant Tween 20 (Sigma-Aldrich, St. Louis, MO, USA) was added at a concentration of $0.05 \%$. The effect of ABA on transpiration was measured $24 \mathrm{~h}$ after spray application using a leaf porometer (SC-1; Meter Group, Pullman, Washington, USA). The Ca mass per fruit and the $\mathrm{Ca} /$ dry mass ratios of fruit and leaves were analyzed at maturity as described above.

\section{Data analysis}

Except for Figs. 1 and 2 data are presented as means \pm SE. Where error bars are not visible in a graph, they are smaller than the plotted symbols. The WVPD was calculated from temperature and relative humidity for every 5 min interval logged using the following equation (Allen et al. 1999):

$\operatorname{WVPD}(\mathrm{kPa})=\left(1-\frac{\mathrm{RH}(\%)}{100}\right) \times 0.611 \times \mathrm{e}^{\frac{17.27 \times \text { Temperature }}{\left.{ }^{\circ} \mathrm{C}\right)}}$

In the next step, the cumulative transpiration of the lowhumidity (high transpiration) treatment was calculated. The increase in mass of the silica in the pottle, which was determined at weekly intervals, was accumulated for the time periods from the initial mounting of the pottle at 13 DAFB until harvest at $27,37,48,58$ or 69 DAFB. Regressing the

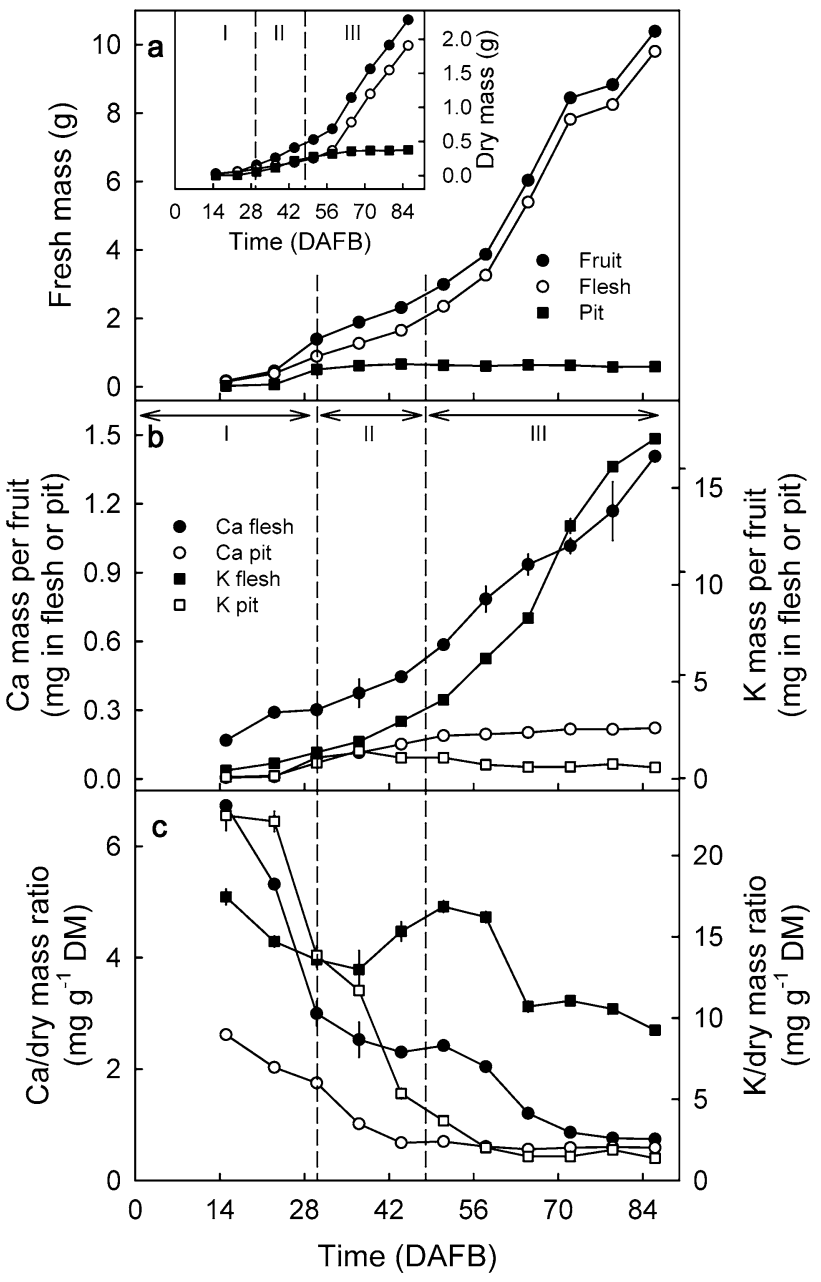

Fig. 2 Developmental time course of change in fresh mass and dry mass (DM) (a) and Ca mass and $\mathrm{K}$ mass per fruit (b) and $\mathrm{Ca} /$ dry mass ratio and $\mathrm{K} /$ dry mass ratio in sweet cherry (c). Dashed vertical lines indicate transition between stage I and II and between stage II and III development

so-obtained cumulative transpiration against the cumulative WVPD in the pottle (calculated for the 5-min intervals as described above and then accumulated for the same time period as the cumulative transpiration was calculated) yielded a significant relationship. The equation was Transpiration $(\mathrm{g})=2.84 \times 10^{-4}\left(\mathrm{~g} \mathrm{kPa}^{-1}\right) \times \mathrm{WVPD}(\mathrm{kPa}), r^{2}$ $=0.97 * *$. This regression equation allowed prediction of transpiration from the WVPD value for the free-hanging control fruit and for the fruit of the high-humidity treatment.

Regression analyses were carried out using $\mathrm{R}$ (function $\mathrm{lm}$, version 3.5.1; R Foundation for Statistical Computing, Vienna, Austria) and SigmaPlot (version 12.5; Systat Software, San Jose, CA, USA). SigmaPlot (version 12.5; Systat Software) was used to create the figures. The significances of coefficients of determination ( $r^{2}$ at $P \leq 0.05,0.01$ and 0.001 ) are indicated by $*, * *$ and $* * *$, respectively. 


\section{Results}

As expected, fruit fresh (FM) mass and dry mass (DM) increased with time (Fig. 3a). The increases resulted primarily from increases in flesh FM and DM. Pit FM and DM increased only until about 37 DAFB (FM) and 65 DAFB $(\mathrm{DM})$ and remained constant thereafter.

Flesh DM (\%) increased only slowly up to about 58 DAFB and then increased rapidly. For the pit, DM (\%) followed a sigmoidal pattern:

$\left(\mathrm{DM}(\%)=5.70+\frac{56.73}{1+\mathrm{e}^{\frac{-(\text { Time }(\mathrm{DAFB})-45.87)}{7.83}}}\right.$, data not shown).

In the flesh, Ca mass per fruit and (especially) $\mathrm{K}$ mass per fruit increased markedly up till maturity (Fig. 3b). In contrast, $\mathrm{Ca}$ and $\mathrm{K}$ mass in the pit increased only to about 51 DAFB. Thereafter, $\mathrm{Ca}$ in the pit remained constant, while $\mathrm{K}$ in the pit decreased (Fig. 3b). On a dry mass ratio basis, $\mathrm{Ca}$ in the flesh decreased to about $30 \%$ during the developmental period and that in the pit to about $84 \%$. In the flesh, the $\mathrm{K} / \mathrm{dry}$ mass ratio decreased from about 15 to $37 \mathrm{DAFB}$
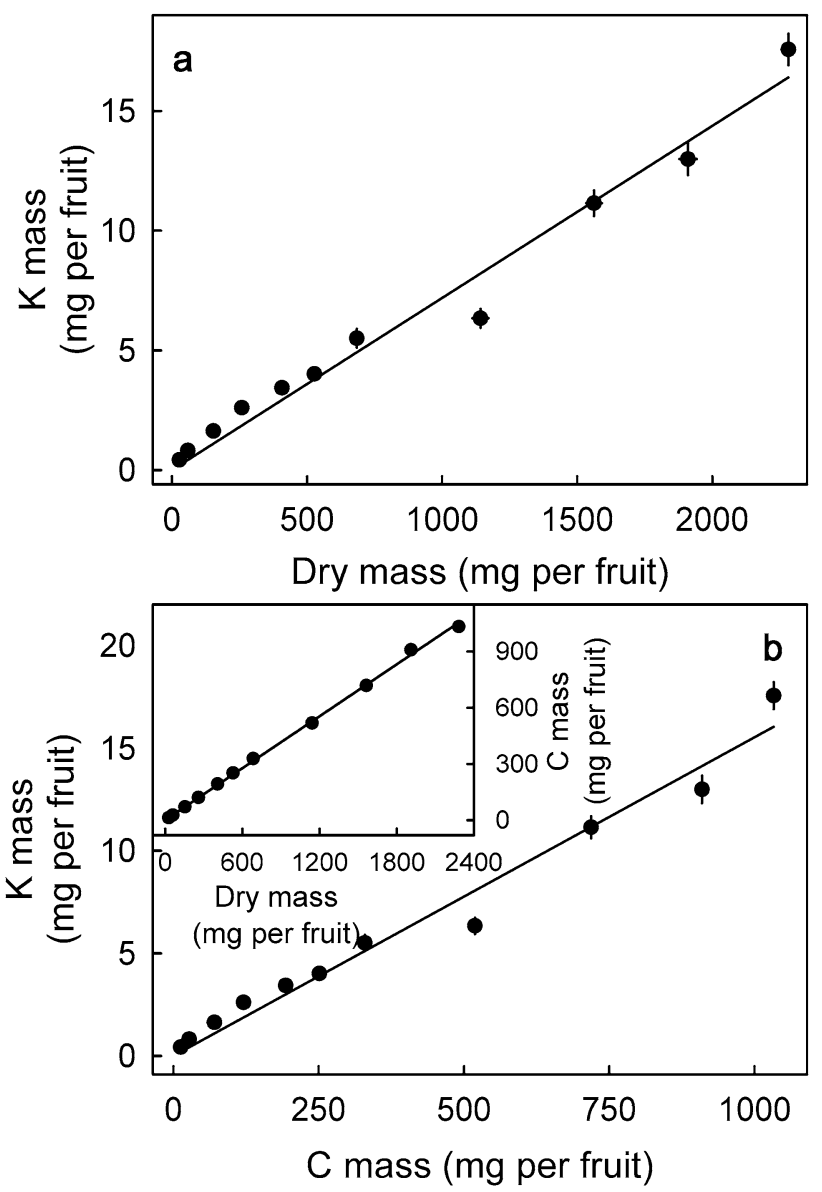

Fig. 3 Relationship between $\mathrm{K}$ mass and the dry mass (a) and the $\mathrm{C}$ mass (b) per fruit of developing sweet cherry. (b inset) Relationship between $\mathrm{C}$ mass per fruit and dry mass per fruit followed by a transient increase from about 37 to 65 DAFB. Thereafter, the $\mathrm{K} /$ dry mass ratio remained about constant. In the pit, the K/dry mass ratio decreased from about $22 \mathrm{mg}$ at 15 DAFB to about $2 \mathrm{mg}$ at 65 DAFB and remained about constant thereafter (Fig. 3c).

The mass of $\mathrm{K}$ per fruit was linearly related to fruit dry mass (Fig. 4a) and the amount of $\mathrm{C}$ per fruit (Fig. 4b) indicating that the $\mathrm{C}$ content of the dry mass was constant (Fig. 4b inset).

The marked decrease of the $\mathrm{Ca} /$ dry mass ratio between fruits at the transition stage II/III and at the mature stage III was not unique for 'Regina', but also occurred to similar extents in other cultivars (Table 1). Marked differences existed between cultivars. At the transition stage II/III, the range was 1.6-fold from the lowest to the highest $\mathrm{Ca}$ /dry mass ratio and this increased to 2.7 -fold at the fully mature stage. The larger range at the mature stage III was due in part to differences among cultivars in the increase in fruit mass that diluted the Ca present.
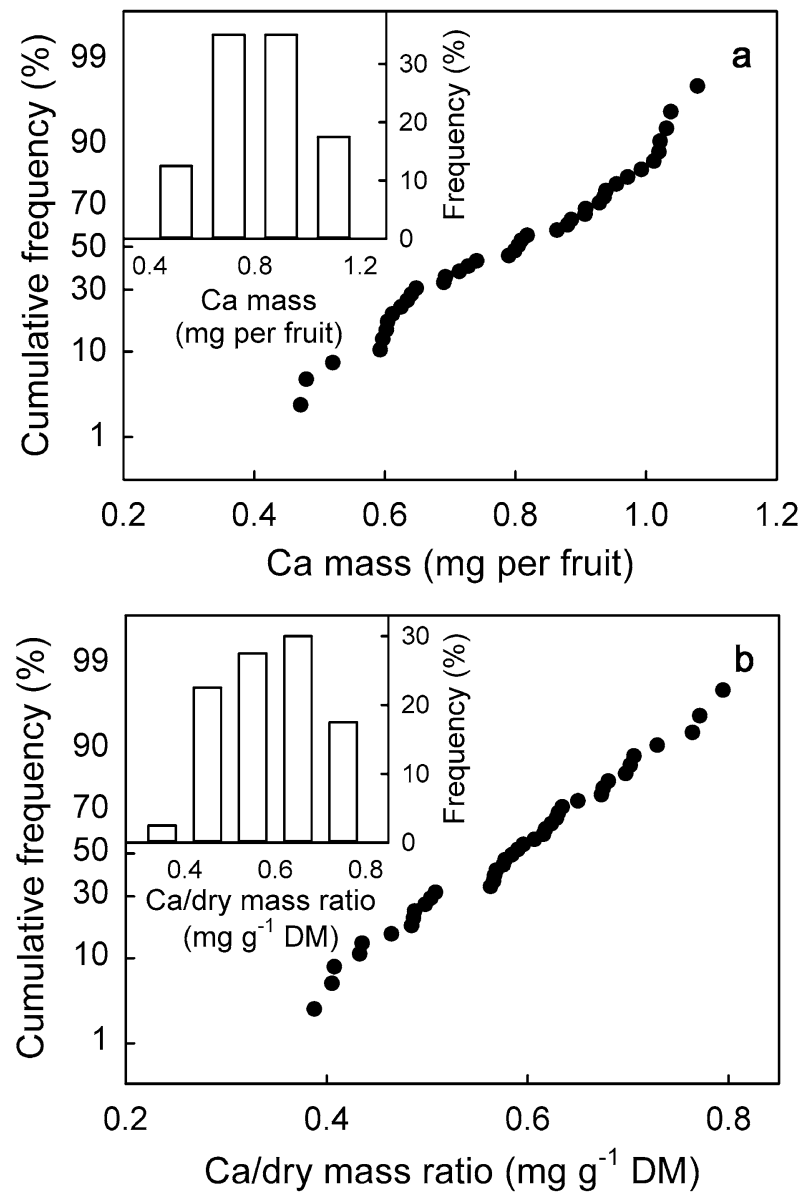

Fig. 4 Normal probability plots of $\mathrm{Ca}$ mass per fruit (a) and the $\mathrm{Ca}$ / dry mass ratio of single sweet cherry fruit (b). Insets: histograms of frequency distributions 
Table 1 Ca mass per fruit and $\mathrm{Ca} / \mathrm{dry}$ mass ratio for various sweet cherry cultivars in immature fruit (transition stage II/III, straw yellow) and in mature fruit (stage III)

\begin{tabular}{|c|c|c|c|c|c|c|}
\hline \multirow[t]{2}{*}{ Cultivar } & \multicolumn{2}{|c|}{ Fruit fresh mass $(\mathrm{g})$} & \multicolumn{2}{|c|}{$\begin{array}{l}\text { Ca mass per fruit (mg per } \\
\text { fruit) }\end{array}$} & \multicolumn{2}{|c|}{$\begin{array}{l}\mathrm{Ca} / \mathrm{dry} \text { mass ratio }\left(\mathrm{mg} \mathrm{g}^{-1}\right. \\
\mathrm{DM})\end{array}$} \\
\hline & Stage II/III & Stage III & Stage II/III & Stage III & Stage II/III & Stage III \\
\hline Adriana & $2.6 \pm 0.0$ & $7.8 \pm 0.4$ & $0.32 \pm 0.02$ & $0.45 \pm 0.02$ & $2.00 \pm 0.10$ & $0.70 \pm 0.04$ \\
\hline Hedelfinger & $3.5 \pm 0.2$ & $8.8 \pm 0.2$ & $0.46 \pm 0.01$ & $0.73 \pm 0.05$ & $1.72 \pm 0.05$ & $0.66 \pm 0.04$ \\
\hline Sam & $3.2 \pm 0.1$ & $10.2 \pm 0.3$ & $0.56 \pm 0.03$ & $0.70 \pm 0.02$ & $2.34 \pm 0.11$ & $0.53 \pm 0.01$ \\
\hline $\begin{array}{l}\text { Schneiders Späte } \\
\text { Knorpel }\end{array}$ & $4.3 \pm 0.1$ & $11.5 \pm 0.1$ & $0.48 \pm 0.01$ & $0.68 \pm 0.02$ & $1.54 \pm 0.03$ & $0.46 \pm 0.02$ \\
\hline Staccato & $2.6 \pm 0.1$ & $7.4 \pm 0.3$ & $0.51 \pm 0.05$ & $0.87 \pm 0.07$ & $2.53 \pm 0.26$ & $1.26 \pm 0.11$ \\
\hline Sweetheart & $2.5 \pm 0.1$ & $6.1 \pm 0.2$ & $0.41 \pm 0.03$ & $0.64 \pm 0.03$ & $2.45 \pm 0.19$ & $1.25 \pm 0.06$ \\
\hline Grand mean & $3.1 \pm 0.1$ & $8.7 \pm 0.4$ & $0.46 \pm 0.02$ & $0.68 \pm 0.03$ & $2.10 \pm 0.10$ & $0.81 \pm 0.08$ \\
\hline
\end{tabular}

The pit was removed before analysis
Table $2 \mathrm{Ca}$ /dry mass ratios in different regions of mature 'Staccato' and 'Sweetheart' sweet cherry fruit

\begin{tabular}{lll}
\hline Region of fruit & \multicolumn{2}{c}{$\mathrm{Ca} /$ dry mass ratio $\left(\mathrm{mg} \mathrm{g}^{-1} \mathrm{DM}\right)$} \\
\cline { 2 - 3 } & Sweetheart & Merchant \\
\hline Stem & $0.86 \pm 0.05$ & $0.36 \pm 0.03$ \\
Stem center & $0.61 \pm 0.04$ & $0.27 \pm 0.01$ \\
Stylar scar center & $0.49 \pm 0.01$ & $0.20 \pm 0.00$ \\
Stylar scar & $0.44 \pm 0.01$ & $0.11 \pm 0.00$ \\
\hline
\end{tabular}

Fruits were cut in the plane normal to the stem/stylar scar axis into four slices of equal thickness. The pit was removed before analysis

The mass of $\mathrm{Ca}$ per fruit and the $\mathrm{Ca} / \mathrm{dry}$ mass ratio followed normal distributions as indicated by the linear normal probability plots. Ranges in $\mathrm{Ca}$ per fruit and $\mathrm{Ca}$ / dry mass ratio were both about twofold, with coefficients of variation of 22.3 and $18.4 \%$, respectively (Fig. 2).

Within a mature sweet cherry fruit, the distribution of $\mathrm{Ca}$ was not uniform. There was a gradient in $\mathrm{Ca}$ along the stem/stylar scar axis. The $\mathrm{Ca} /$ dry mass ratios were two('Sweetheart') to threefold ('Merchant') higher in the stem end than in the stylar scar end (Table 2).

There were no significant effects of the position of the fruit in the canopy on fruit size, Ca per fruit or $\mathrm{Ca}$ /dry mass ratios (results not shown).

Manipulating the $\mathrm{RH}$ around individual fruit in the greenhouse resulted in significant effects on Ca per fruit and on $\mathrm{Ca} /$ dry mass ratio. The effects on fruit size were generally not significant. Fruits held under a low-RH environment (high transpiration) were slightly smaller than others held under a high-RH environment (low transpiration) (Fig. 5a). Free-hanging control fruit exposed to a variable and intermediate RH environment (variable and intermediate transpiration) tended to be largest. There were no differences in the temperatures between the freehanging control fruit and the fruit enclosed in the pottles as well as between the low- $\mathrm{RH}$ and high- $\mathrm{RH}$ pottles (data not shown).

The low-RH fruit generally had a significantly higher Ca mass per fruit and a higher $\mathrm{Ca} /$ dry mass ratio compared with that of the high-RH fruit (Fig. 5b, c). Control fruit exposed to the greenhouse climate was intermediate in Ca mass per fruit and $\mathrm{Ca} /$ dry mass ratio. Consistent with the developmental time course study, $\mathrm{Ca}$ /dry mass ratios decreased during development under all treatments. The difference in Ca mass per fruit resulted from differences in cumulative transpiration. The low-RH environment resulted in high cumulative transpiration and, vice versa, the high-RH environment resulted in low cumulative transpiration (Fig. 6a). The freehanging control fruit was intermediate (Fig. 6a). These differences were all significant. Expressing $\mathrm{Ca}$ mass per fruit as a function of cumulative transpiration revealed a positive, non-linear relationship (Fig. 6b). As cumulative transpiration increased, Ca mass per fruit increased at a decreasing rate, i.e., the curve tended to asymptote for values of high cumulative transpiration.

Spray application of ABA decreased stomatal conductance of leaves by about 20\% (Table 3). However, there was no effect on either the fruit or the leaf $\mathrm{Ca} / \mathrm{dry}$ mass ratios or the $\mathrm{Ca}$ mass per fruit (Table 3).

\section{Discussion}

The results indicate (1) that the import of Ca into developing sweet cherries does not keep pace with the increase in fruit mass and (2) that Ca import into developing sweet cherry is positively related to changes in fruit transpiration.

\section{Ca import does not keep pace with fruit growth}

The increase in Ca mass per fruit lagged behind the increase in fruit $\mathrm{FM}$ and DM. As a consequence, $\mathrm{Ca}$ /dry mass ratio 


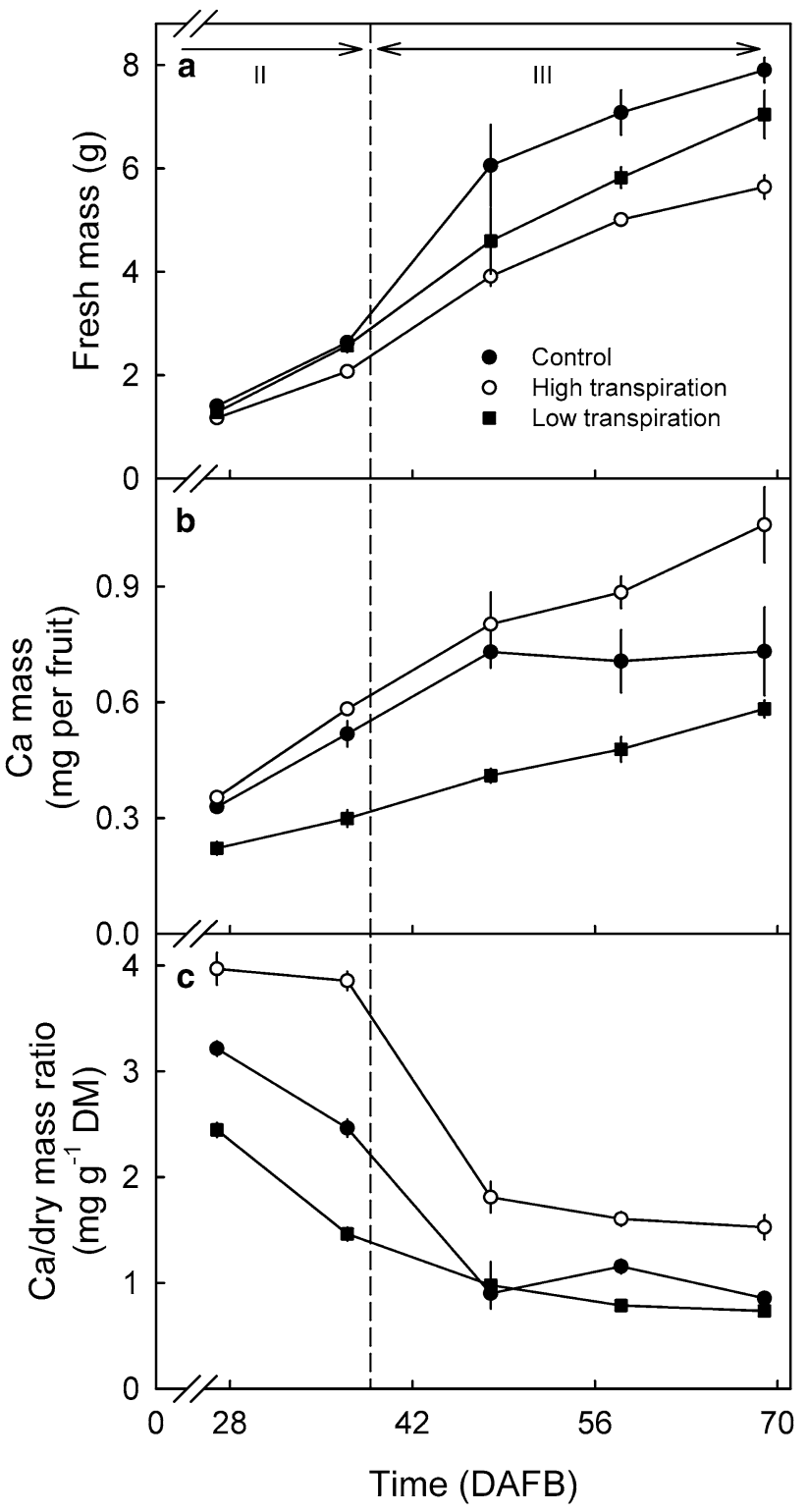

Fig. 5 Developmental time course of change in fruit fresh mass (a), $\mathrm{Ca}$ mass per fruit (b) and $\mathrm{Ca} /$ dry mass ratio of developing sweet cherry (c). The developmental time courses were established for fruit held at low relative humidity (RH) (mean 26.2\%) or high RH (mean 91.6\%). The low RH was established by sealing a still-attached fruit in a plastic pottle containing dry silica gel. The high RH was established by sealing a still-attached fruit in an empty pottle. Free-hanging, still-attached fruit exposed to the greenhouse atmosphere served as controls (mean RH 76.4\%). DM dry mass. The dashed vertical line indicates the transition from stage II to stage III

decreased. This effect is not unique to 'Regina', but has also been observed in 'Sam' (Fiedler, unpublished data) and in 'Lambert' (Facteau 1982). In the latter cultivar, Ca mass per fruit remained constant during the last 2 weeks before harvest. Decreases in $\mathrm{Ca} /$ dry mass ratio during fruit development have also been reported in apple (Amarante et al. 2013), bean, pepper, quince (Mix and Marschner 1976a, b),
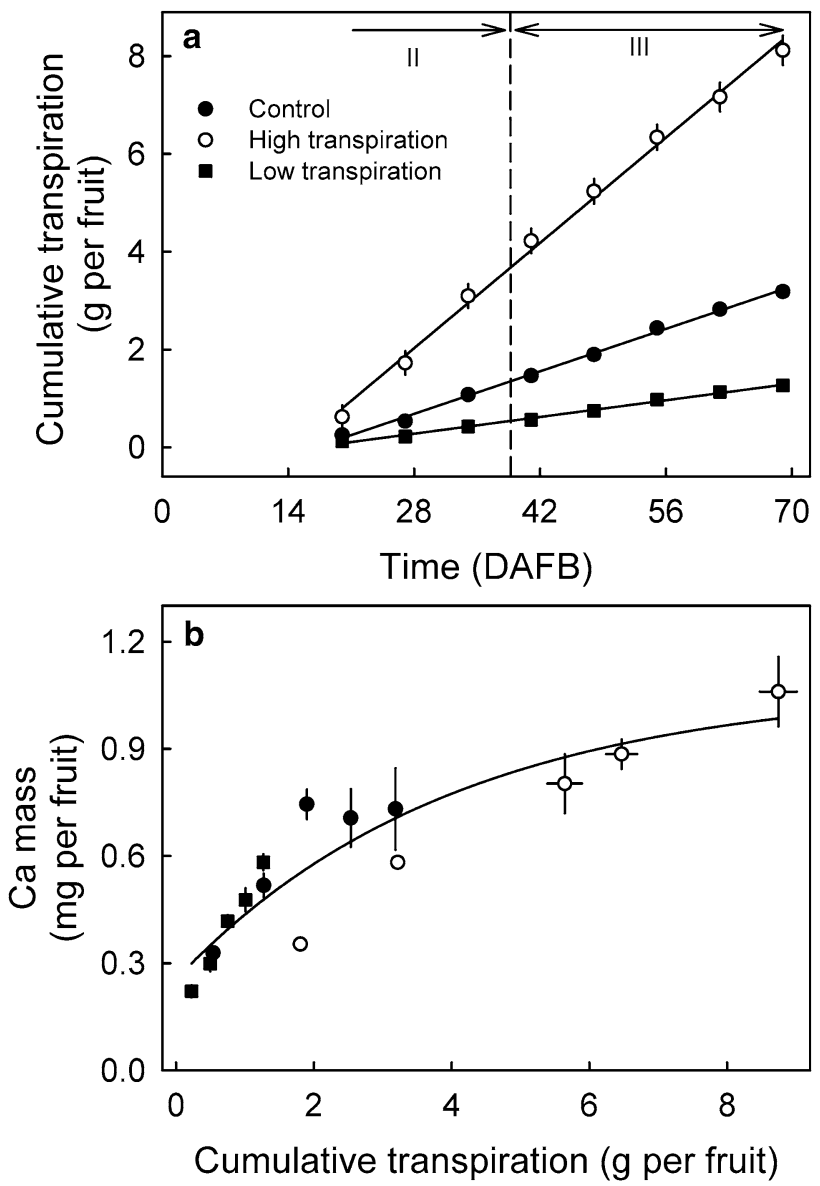

Fig. 6 a Cumulative transpiration and $\mathbf{b}$ Ca mass per fruit of developing sweet cherry that remained attached to the tree and held at low relative humidity (RH) (mean 26.2\%) or high $\mathrm{RH}$ (mean 91.6\%). The low RH was established by sealing a still-attached fruit in a plastic pottle containing dry silica gel. The high RH was established by sealing a still-attached fruit in an empty plastic pottle. Free-hanging, stillattached fruit exposed to the greenhouse atmosphere served as controls (mean RH 76.4\%). The dashed vertical line in a indicates the transition from stage II to stage III

Table 3 Effect of abscisic acid (ABA) applications on stomatal conductance, the Ca mass per fruit and the $\mathrm{Ca} /$ dry mass ratio of sweet cherry fruit and leaves

\begin{tabular}{|c|c|c|c|c|}
\hline \multirow[t]{2}{*}{ Treatment } & \multirow{2}{*}{$\begin{array}{l}\text { Stomatal } \\
\text { conductance } \\
\left(\text { mmol } \mathrm{m}^{-2} \mathrm{~s}^{-1}\right) \\
\text { Leaves }\end{array}$} & \multirow{2}{*}{$\begin{array}{l}\text { Ca mass per } \\
\text { fruit (mg per } \\
\text { fruit) } \\
\text { Fruit }\end{array}$} & \multicolumn{2}{|c|}{$\begin{array}{l}\mathrm{Ca} / \text { dry mass ratio (mg } \\
\left.\mathrm{g}^{-1} \mathrm{DM}\right)\end{array}$} \\
\hline & & & Fruit & Leaves \\
\hline Control & $591 \pm 25$ & $0.87 \pm 0.05$ & $0.48 \pm 0.03$ & $16.9 \pm 0.5$ \\
\hline ABA & $465 \pm 28$ & $0.88 \pm 0.06$ & $0.49 \pm 0.04$ & $14.5 \pm 0.8$ \\
\hline
\end{tabular}

ABA (400 $\mathrm{mg}^{-1}$ ) was applied at weekly intervals from 5 DAFB to harvest

kiwifruit (Clark and Smith 1991; Xiloyannis et al. 2001), mango (Joyce et al. 2001), papaya (Qiu et al. 1995) and tomato (Ehret and Ho 1986). 
$\mathrm{Ca}$ translocation is limited to the xylem (Marschner 1995). Thus, the lack of proportionality between fruit growth and fruit $\mathrm{Ca}$ import was likely due to a progressive loss of xylem functionality in the developing sweet cherry. During stage III, the contribution of xylem water inflow to the fruit decreases from $95 \%$ of total inflow at the transition stage II/ III to about 5\% of the total at the mature stage III (Brüggenwirth et al. 2016; Winkler et al. 2016). Furthermore, the decrease in xylem functionality occurs progressively, beginning at the stylar end and progressing towards the stem end (Grimm et al. 2017; Winkler et al. 2016). Accordingly, the lowest $\mathrm{Ca}$ /dry mass ratio was recorded in the stylar scar end, where xylem functionality was first lost; and the highest $\mathrm{Ca}$ / dry mass ratio was recorded in the stem end of the fruit, where the xylem remained functional through to maturity (Grimm et al. 2017; Winkler et al. 2016). Similar observations have been reported for apple (Lewis and Martin 1973), avocado (Burdon et al. 1991; Chaplin and Scott 1980), sweet pepper (Marcelis and Ho 1999) and tomato (Adams and Ho 1993; Ehret and Ho 1986; Nonami et al. 1995). Thus, xylem functionality seems to be the primary determinant of fruit Ca distribution within a sweet cherry.

In contrast to $\mathrm{Ca}$, plant organs that are preferentially supplied by phloem sap such as fruit are typically rich in K (Mengel and Kirkby 1982). It is, therefore, not surprising that the $\mathrm{K}$ mass per fruit and the $\mathrm{K} /$ dry mass ratio both increased linearly with the increase in fruit dry matter and, hence, with total C import into the fruit. During stage III, water inflow via the phloem accounts for an increasing proportion of the total inflow until, at maturity, essentially all water inflow to the fruit occurs via the phloem (Brüggenwirth et al. 2016). This explains why the K/dry mass ratio changes only slightly during fruit development. The transient increase in $\mathrm{K} /$ dry mass ratio between 42 and 68 DAFB is difficult to explain. This effect was not due to biological variation, but it was reproducible in 'Sam' sweet cherry during another growing season (Fiedler, unpublished data).

\section{Increased transpiration increases Ca import to the fruit}

Our results establish a close relationship between fruit transpiration and $\mathrm{Ca}$ import to sweet cherry. Low-transpiration fruits had a Ca mass of about $0.6 \mathrm{mg}$ per fruit at maturity, while high-transpiration fruits had a $\mathrm{Ca}$ mass averaging about $1.1 \mathrm{mg}$ per fruit. This relationship is not linear, with the nearly twofold increase in fruit $\mathrm{Ca}$ being associated with a nearly 6.4-fold increase in fruit transpiration (Fig. 6b). Increases in fruit $\mathrm{Ca}$ with increased transpiration have also been observed in apple (Cline and Hanson 1992), kiwifruit (Montanaro et al. 2015) and snap bean (Grusak and Pomper 1999). Also, as in sweet cherry, the relationship between fruit transpiration and fruit $\mathrm{Ca}$ content was not linear in apple (Tromp and Vanvuure 1993) or in kiwifruit (Montanaro et al. 2015).

These observations are accounted for by the progressive change in xylem functionality in developing fruit. At the stage II/III transition, the xylem is fully functional and xylem flow and fruit transpiration are closely related (Brüggenwirth et al. 2016). After the stage II/III transition, transpiration becomes increasingly independent of xylem inflow as the latter tends to decrease (Brüggenwirth et al. 2016; Winkler et al. 2016). Thus, during early development, fruit transpiration has a strong effect on fruit $\mathrm{Ca}$ import, but the effect is much weaker at later stage III and at maturity.

Furthermore, convective flow within the xylem sap is not the only mechanism of Ca transport. Three additional mechanisms are involved. (1) Ca translocation occurs by movement along $\mathrm{Ca}$-exchange sites on the walls of vessels and pit membranes of the xylem (Clarkson 1984; Kuhn et al. 1995). (2) The acropetal Ca transport is linked to the basipetal auxin transport. An inhibition of basipetal transport of IAA restricts the acropetal transport of $\mathrm{Ca}$ (Banuelos et al. 1987; Tomala and Dilley 1990). (3) Transport of Ca also occurs via $\mathrm{Ca}^{2+}$-transporters or $\mathrm{Ca}^{2+}$-binding proteins (Hirschi 2004; Park et al. 2005). The combined effects of all three mechanisms would account for the lack of a simple linear relationship between cumulative fruit transpiration and cumulative fruit $\mathrm{Ca}$ mass. These effects may also account for the absence of any consistent effects of position in the canopy on fruit Ca mass. We expected fruit high in the canopy to experience higher transpiration and, hence, to exhibit higher Ca mass per fruit than the more shaded fruit in the base or center of the canopy. This was not the case.

\section{Practical implications}

The influx of Ca to developing fruit is slowed by the progressive loss of xylem function. Hence, agronomic practices that may increase fruit transpiration may also increase fruit $\mathrm{Ca}-$ but only if these are applied early on in fruit development. These practices might include a more open canopy structure. Closing of rain shelters at (or shortly after) bloom will keep the canopy and the fruit surfaces dry and will also increase their temperature. Provided proper ventilation also occurs, these conditions (i.e., warmer and drier) will increase the water vapor pressure deficit, and hence fruit transpiration, and hence fruit $\mathrm{Ca}$ Whether the resulting increases in fruit $\mathrm{Ca}$ are sufficient to significantly reduce cracking susceptibility has yet to be demonstrated.

Author contribution statement MK obtained the funds to support the study. MK and AW planned the experiments. AW and BF conducted the experiments. MK and AW analysed the data, wrote, revised and edited the manuscript. 
Acknowledgements Open Access funding provided by Projekt DEAL. We thank Friederike Schroeder and Simon Sitzenstock for technical support, Dr. Sandy Lang for helpful comments on an earlier version of this manuscript and Dr. Peter D. Petracek, Valent BioSciences, Libertyville, for the gift of ProTone. This research was funded in part by a grant from the Deutsche Forschungsgemeinschaft (KN402/14-1).

\section{Compliance with ethical standards}

Conflict of interest The authors declare that they have no conflict of interest.

Open Access This article is licensed under a Creative Commons Attribution 4.0 International License, which permits use, sharing, adaptation, distribution and reproduction in any medium or format, as long as you give appropriate credit to the original author(s) and the source, provide a link to the Creative Commons licence, and indicate if changes were made. The images or other third party material in this article are included in the article's Creative Commons licence, unless indicated otherwise in a credit line to the material. If material is not included in the article's Creative Commons licence and your intended use is not permitted by statutory regulation or exceeds the permitted use, you will need to obtain permission directly from the copyright holder. To view a copy of this licence, visit http://creativecommons.org/licenses/by/4.0/.

\section{References}

Adams P, Ho LC (1993) Effects of environment on the uptake and distribution of calcium in tomato and on the incidence of blossom-end rot. Plant Soil 154:127-132. https://doi.org/10.1007/ Bf00011081

Allen RG, Pereira LS, Raes D, Smith M (1999) Crop evapotranspiration. Guidelines for computing crop water requirements. FAO Irrigation and Drainage Paper No 56 FAO, Rome

Amarante CVT, Miqueloto A, Steffens CA, dos Santos A, Argenta LC (2013) Changes in xylem functionality during apple fruit development: Implications on calcium concentration and incidence of bitter pit. Acta Hortic 1012:135-140. https://doi. org/10.17660/ActaHortic.2013.1012.11

Banuelos GS, Bangerth F, Marschner H (1987) Relationship between polar basipetal auxin transport and acropetal $\mathrm{Ca}^{2+}$ transport into tomato fruits. Physiol Plant 71:321-327. https://doi. org/10.1111/j.1399-3054.1987.tb04350.x

Brüggenwirth M, Winkler A, Knoche M (2016) Xylem, phloem, and transpiration flows in developing sweet cherry fruit. Trees 30:1821-1830. https://doi.org/10.1007/s00468-016-1415-4

Bullock RM (1952) A study of some inorganic compounds and growth promoting chemicals in relation to fruit cracking of Bing cherries at maturity. Proc Am Soc Hortic Sci 56:243-253

Burdon JN, Moore KG, Wainwright H (1991) Mineral distribution in mango fruit susceptible to the physiological disorder softnose. Sci Hortic 48:329-336. https://doi.org/10.1016/03044238(91)90143-M

Callan NW (1986) Calcium hydroxide reduces splitting of 'Lambert' sweet cherry. J Am Soc Hortic Sci 111:173-175

Chan SY, Choo WS, Young DJ, Loh XJ (2017) Pectin as a rheology modifier: origin, structure, commercial production and rheology. Carbohydr Polym 161:118-139. https://doi.org/10.1016/j. carbpol.2016.12.033
Chaplin GR, Scott KJ (1980) Association of calcium in chilling injury susceptibility of stored avocados. HortScience 15:514-515

Clark CJ, Smith GS (1991) Seasonal changes in the form and distribution of calcium in fruit of kiwifruit vines. J Hortic Sci 66:747753. https://doi.org/10.1080/00221589.1991.11516207

Clarkson DT (1984) Calcium transport between tissues and its distribution in the plant. Plant Cell Environ 7:449-456. https://doi. org/10.1111/j.1365-3040.1984.tb01435.x

Cline JA, Hanson EJ (1992) Relative humidity around apple fruit influences its accumulation of calcium. J Am Soc Hortic Sci 117:542546. https://doi.org/10.21273/JASHS.117.4.542

Conway WS, Sams CE, Hickey KD (2002) Pre- and postharvest calcium treatment of apple fruit and its effect on quality. Acta Hortic 594:413-419. https://doi.org/10.17660/ActaHortic.2002.594.53

de Freitas ST, McElrone AJ, Shackel KA, Mitcham EJ (2014) Calcium partitioning and allocation and blossom-end rot development in tomato plants in response to whole-plant and fruit-specific abscisic acid treatments. J Exp Bot 65:235-247. https://doi. org/10.1093/jxb/ert364

Demarty M, Morvan C, Thellier M (1984) Calcium and the cell wall. Plant Cell Environ 7:441-448. https://doi. org/10.1111/j.1365-3040.1984.tb01434.x

Ehret DL, Ho LC (1986) Translocation of calcium in relation to tomato fruit growth. Ann Bot 58:679-688. https://doi. org/10.1093/oxfordjournals.aob.a087230

Facteau TJ (1982) Levels of pectic substances and calcium in gibberellic acid-treated sweet cherry fruit. J Am Soc Hortic Sci 107:148-151

Fishman MJ, Downs SC (1966) Methods for analysis of selected metals in water by atomic absorption. Geological surves watersupply paper $1540-$ C. U.S. Government Printing Office, Washington, DC

Garcia JM, Ballesteros JM, Albi MA (1995) Effect of foliar applications of $\mathrm{CaCl}_{2}$ on tomato stored at different temperatures. J Agric Food Chem 43:9-12. https://doi.org/10.1021/jf00049a003

Glenn GM, Poovaiah BW (1989) Cuticular properties and postharvest calcium applications influence cracking of sweet cherries. J Am Soc Hortic Sci 114:781-788

Grimm E, Pflugfelder D, van Dusschoten D, Winkler A, Knoche M (2017) Physical rupture of the xylem in developing sweet cherry fruit causes progressive decline in xylem sap inflow rate. Planta 246:659-672. https://doi.org/10.1007/s00425-017-2719-3

Grusak MA, Pomper KW (1999) Influence of pod stomatal density and pod transpiration on the calcium concentration of snap bean pods. J Am Soc Hortic Sci 124:194-198. https://doi.org/10.21273 /Jashs.124.2.194

Hardingham GE, Bading $\mathrm{H}$ (1999) Calcium as a versatile second messenger in the control of gene expression. Microsc Res Tech 46:348-355. https://doi.org/10.1002/ (Sici) 1097-0029(19990915)46:6<348::Aid-Jemt3>3.3.Co;2-1

Hepler PK (2005) Calcium: A central regulator of plant growth and development. Plant Cell 17:2142-2155. https://doi.org/10.1105/ tpc. 105.032508

Hirschi KD (2004) The calcium conundrum. Both versatile nutrient and specific signal. Plant Physiol 136:2438-2442. https://doi. org/10.1104/pp.104.046490

Islam MZ, Mele MA, Baek JP, Kang HM (2016) Cherry tomato qualities affected by foliar spraying with boron and calcium. Hortic Environ Biotechnol 57:46-52. https://doi.org/10.1007/s1358 0-016-0097-6

Joyce DC, Shorter AJ, Hockings PD (2001) Mango fruit calcium levels and the effect of postharvest calcium infiltration at different maturities. Sci Hortic 91:81-99. https://doi.org/10.1016/S0304 $-4238(01) 00247-3$ 
Koffmann W, Wade NL, Nicol H (1996) Tree sprays and root pruning fail to control rain induced cracking of sweet cherries. Plant Prot Q 11:126-130

Kuhn AJ, Bauch J, Schröder WH (1995) Monitoring uptake and contents of $\mathrm{Mg}, \mathrm{Ca}$ and $\mathrm{K}$ in Norway spruce as influenced by $\mathrm{pH}$ and $\mathrm{Al}$, using microprobe analysis and stable isotope labelling. Plant Soil 168:135-150. https://doi.org/10.1007/Bf00029322

Lang A (1990) Xylem, phloem and transpiration flows in developing apple fruits. J Exp Bot 41:645-651. https://doi.org/10.1093/ $\mathrm{jxb} / 41.6 .645$

Lewis TL, Martin D (1973) Longitudinal distribution of applied calcium, and of naturally occurring calcium, magnesium, and potassium, in Merton apple fruits. Aust J Agric Res 24:363-371. https ://doi.org/10.1071/Ar9730363

Looney NE (1985) Benefits of calcium sprays below expectations in B.C. tests. GoodFruit Grower 36:7-8

Marcelis LFM, Ho LC (1999) Blossom-end rot in relation to growth rate and calcium content in fruits of sweet pepper (Capsicum annuит L.). J Exp Bot 50:357-363. https://doi.org/10.1093/ $\mathrm{jxb} / 50.332 .357$

Marschner H (1995) Mineral nutrition of higher plants, 2nd edn. Academic Press, London

Meheriuk M, Neilsen GH, McKenzie D-L (1991) Incidence of rain splitting in sweet cherries treated with calcium or coating materials. Can J Plant Sci 71:231-234. https://doi.org/10.4141/cjps9 $1-032$

Mengel K, Kirkby EA (1982) Principles of plant nutrition, 3rd edn. International Potash Institute Bern, Switzerland

Michailidis M, Karagiannis E, Tanou G, Karamanoli K, Lazaridou A, Matsi T, Molassiotis A (2017) Metabolomic and physico-chemical approach unravel dynamic regulation of calcium in sweet cherry fruit physiology. Plant Physiol Biochem 116:68-79. https://doi. org/10.1016/j.plaphy.2017.05.005

Mix GP, Marschner H (1976a) Calciumgehalte in Früchten von Paprika, Bohne, Quitte und Hagebutte im Verlauf des Fruchtwachstums. Z Pflanzenernähr Bodenkd 5:537-549

Mix GP, Marschner H (1976b) Einfluß exogener und endogener Faktoren auf den Calciumgehalt von Paprika- und Bohnenfrüchten. Z Pflanzenernähr Bodenkd 5:551-563

Montanaro G, Dichio B, Lang A, Mininni AN, Xiloyannis C (2015) Fruit calcium accumulation coupled and uncoupled from its transpiration in kiwifruit. J Plant Physiol 181:67-74. https://doi. org/10.1016/j.jplph.2015.04.004

Nonami H, Fukuyama T, Yamamoto M, Yang L, Hashimoto Y (1995) Blossom-end rot of tomato plants may not be directly caused by calcium deficiency. Acta Hortic 396:107-114. https://doi. org/10.17660/ActaHortic.1995.396.11
Park S, Cheng NH, Pittman JK, Yoo KS, Park J, Smith RH, Hirschi KD (2005) Increased calcium levels and prolonged shelf life in tomatoes expressing Arabidopsis $\mathrm{H}^{+} / \mathrm{Ca}^{2+}$ transporters. Plant Physiol 139:1194-1206. https://doi.org/10.1104/pp.105.066266

Poovaiah BW, Leopold AC (1973) Deferral of leaf senescence with calcium. Plant Physiol 52:236-239. https://doi.org/10.1104/ pp.52.3.236

Qiu YX, Nishina MS, Paull RE (1995) Papaya fruit growth, calcium uptake, and fruit ripening. J Am Soc Hortic Sci 120:246-253. https://doi.org/10.21273/JASHS.120.2.246

Schlegel TK, Schönherr J (2002) Stage of development affects penetration of calcium chloride into apple fruits. J Plant Soil Sci 165:738-745. https://doi.org/10.1002/jpln.200290012

Steinhorst L, Kudla J (2014) Signaling in cells and organisms - calcium holds the line. Curr Opin Plant Biol 22:14-21. https://doi. org/10.1016/j.pbi.2014.08.003

Tomala K, Dilley DR (1990) Some factors influencing the calcium level in apple fruits. Acta Hortic 274:481-488. https://doi.org/10.17660 /ActaHortic.1990.274.61

Tromp J, Vanvuure J (1993) Accumulation of calcium, potassium and magnesium in apple fruits under various conditions of humidity. Physiol Plant 89:149-156. https://doi. org/10.1111/j.1399-3054.1993.tb01798.x

van Steveninck RFM (1965) The significance of calcium on the apparent permeability of cell membranes and the effects of substitution with other divalent ions. Physiol Plant 18:54-69. https://doi. org/10.1111/j.1399-3054.1965.tb06869.x

Winkler A, Brüggenwirth M, Ngo NS, Knoche M (2016) Fruit apoplast tension draws xylem water into mature sweet cherries. Sci Hortic 209:270-278. https://doi.org/10.1016/j.scienta.2016.06.041

Winkler A, Knoche M (2019) Calcium and the physiology of sweet cherries: a review. Sci Hortic 245:107-115. https://doi. org/10.1016/j.scienta.2018.10.012

Xiloyannis C, Celano G, Montanaro G, Dichio B, Sebastiani L, Minnocci A (2001) Water relations, calcium and potassium concentration in fruits and leaves during annual growth in mature kiwifruit plants. Acta Hortic. https://doi.org/10.17660/ActaHortic .2001 .564 .14

Publisher's Note Springer Nature remains neutral with regard to jurisdictional claims in published maps and institutional affiliations. 